\title{
FITNESS INDUSTRY BUSINESS MODELS: FROM THE TRADITIONAL FRANCHISING CHAIN TO THE FITNESS BOUTIQUE
}

Silvio Addolorato (Ph. D.) Assistant Professor

Exercise and Sport Science Degree Course Catholic University of the Sacred Heart

Milan, Italy silvio.addolorato@unicatt.it

Jorge García-Unanue (Ph. D.) Associate Professor IGOID Research Group, Department of Physical Activity and Sport Sciences University of Castilla-La Mancha

Toledo, Spain jorge.garciaunanue@uclm.es

Leonor Gallardo (Ph. D.) Full Professor IGOID Research Group, Department of Physical Activity and Sport Sciences University of Castilla-La Mancha Toledo, Spain leonor.gallardo@uclm.es

Jerónimo García-Fernández (Ph. D.) Associate Professor GISDOR Research Group, Physical Education and Sport Department University of Seville, Spain jeronimo@us.es

\begin{abstract}
Objective of the study: Fitness centres or "gyms" nowadays represent a real need for human beings in daily life routines worldwide. Through an exhaustive analysis of the literature has been possible to define the concept of the fitness boutique by analysing the current state of the art of scientific publications on business configurations/schemes and during the postmodern fitness industry timeline available until now.

Methodology: Regarding the study design, three main databases have been utilised: ISI-WoS, Scopus, and SportDiscus. The following combination of search was employed: "fitness" intersected with "chain", "studio" and "franchise".

Originality/Relevance: The research and keywords utilised revealed about 33 articles, and three thematic areas have been sorted: (1) franchise: from $1^{\text {st }}$ to $2^{\text {nd }}$ generation; (2) the boutique "essence"; and (3) social responses.

Main results: Above all, the eight (8) main untouchable-qualitative features obtained of the fitness boutique model have been listed.

Theoretical/methodological contributions: The research points out how the fitness industry evolved with its proper business and market models during the most recent timeline.

Social/managerial contributions: This study could (1) assist researchers and professional alike in familiarising themselves with the extent of work published in the most relevant sports and leisure databases, and (2) in understanding all the qualitative secrets and successes of the franchising schemes inside the fitness field.
\end{abstract}

Keywords: Fitness boutique. Fitness industry. Fitness settings. Business models. Service experience.

\section{Cite como}

American Psychological Association (APA)

Addolorato, S., García-Unanue, J., Gallardo, L., \& García-Fernández, J. (2022, jan./abr.). Fitness industry business models: from the traditional franchising chain to the fitness boutique. PODIUM Sport, Leisure and Tourism Review, São Paulo, 11(1), 1-25. https://doi.org/10.5585/podium.v11i1.18287. 


\section{MODELOS DE NEGÓCIOS NA INDÚSTRIA DA FITNESS: DESDE A CADEIA DE FRANQUIA TRADICIONAL À LA FITNESS BOUTIQUE}

\section{Resumo}

Objetivo do estudo: Os centros de fitness o ginásios representam hoje uma necessidade real dos seres humanos dentro das rotinas da vida cotidiana em todo o mundo. Através de uma análise exaustiva da literatura, pretendemos definir o conceito de boutique de fitness através da análise do estado atual das publicações científicas sobre configurações/esquemas de negócios y durante a linha do tempo da indústria de fitness pós-moderna.

Metdologia: Três principais bases de dados foram utilizadas para obter os resultados: ISI-WoS, Scopus e SportDiscus. A seguinte combinação de pesquisa foi usada: o termo "fitness" cruzado com "chain", "studio" e "franchise".

Originalidade/Relevância: Os resultados foram ordenados de acordo com três áreas temáticas: (1) franquia: da $1^{\mathrm{a}}$ à $2^{\mathrm{a}}$ geração; (2) a boutique "essência"; e (3) respostas sociais.

Principais resultados: As oito (8) principais características qualitativas intangíveis obtidas a partir do modelo de fitness boutique foram listadas.

Contribuições teóricas/metodológicas: A pesquisa mostra como a indústria evoluiu com seus próprios modelos de negócios/mercado ao longo do tempo mais recente.

Contribuições sociais/para a gestão: Este estudo poderia (1) ajudar pesquisadores e profissionais a se familiarizarem com o escopo dos trabalhos mais relevantes publicados nas bases de dados de esportes e ócio, e (2) a compreender todos os segredos e sucessos qualitativos dos esquemas franquia no domínio do fitness.

Palavras-chave: Configurações de fitness. Experiência de serviço. Fitness boutique. Indústria de fitness. Modelos de negócios.

\section{MODELOS DE NEGOCIO EN LA INDUSTRIA DEL FITNESS: DESDE LA CADENA DE FRANQUICIA TRADICIONAL A LA FITNESS BOUTIQUE}

\section{Resumen}

Objetivo del estudio: Los centros de fitness o "gimnasios" representan una necesidad real para los seres humanos dentro de las rutinas de la vida diaria en todo el mundo. A través de un análisis exhaustivo de la literatura se quiere llegar a definir el concepto de la fitness boutique por medio del análisis del estado actual de las publicaciones científicas al respecto de las configuraciones/esquemas de negocios y durante la línea de tiempo de la industria del fitness posmoderna.

Metodología: Tres principales bases de datos se han utilizados para conseguir los hallazgos: ISI-WoS, Scopus y SportDiscus. Se utilizó la siguiente combinación de búsqueda: el término "fitness" intersectado con "chain", "studio" y "franchise".

Originalidad/Relevancia: Los resultados se han ordenado según tres áreas temáticas: (1) franquicia: de $1^{\mathrm{a}}$ a $2^{\mathrm{a}}$ generación; (2) la "esencia" boutique; y (3) respuestas sociales.

Resultados principales: Se han enumerado las ocho (8) principales características cualitativas inmateriales obtenidas del modelo de boutique del fitness.

Contribuciones teóricas/metodológicas: La investigación señala cómo la industria evolucionó con sus propios modelos de negocio/mercado durante la línea de tiempo más reciente.

Contribuciones sociales/gerenciales: Este estudio podría (1) ayudar de igual forma a investigadores y profesionales a familiarizarse con el alcance de los trabajos más relevantes publicados en las bases de datos de deportes y ocio, y (2) a comprender todos los secretos y éxitos cualitativos de los esquemas de franquicia dentro del campo del fitness.

Palabras clave: Configuraciones del fitness. Experiencia del servicio. Fitness boutique. Industria del fitness. Modelos de negocio. 
Addolorato, S., García-Unanue, J., Gallardo, L., \& García-Fernández, J. (2022, jan./abr.). Fitness industry business models: from the traditional franchising chain to the fitness boutique

\section{Literature review}

\section{The postmodern fitness}

Since the 1970's, the fitness industry has developed as a commercial field with its network of producers, consumers, products, services, and practices that focus on exercising the body (Smith Maguire, 2002). The essay suggests that contemporary fitness practices share aesthetic and ideological commitments with other activities that have been classified as postmodern (Glassner, 1989). The aesthetic similarities are evident in the use of pastiche and simulation by manufacturers of exercise machine and videotapes, among others. In terms of ideology, the pursuit of fitness is promoted as an opportunity for individuals to avert several of the risks to selfhood thought to be present in modern social organisations. Urban (but not only) enterprises, in a capitalism world, increasingly find that what is essential to their competitive success is their ability to sell not mere commodities (social statuses, material assets in possession, etc.) but icons (products and services, for the sector selected) that gain market value by presenting appealing images (Sternberg, 1996). This corresponds to what literature labelled as postmodern "landscape"; in it, these sectoral firms, reflect the working dynamics of market capitalism in which a wide variety of iconographic strategies are building realities that touch several aspects of this new societal scenario.

Fitness does not necessarily need to be associated with leisure; in fact, historically, exercising has also been linked with the military, work preparedness, religion, and moral character building as well as with therapeutic health regimes (Smith Maguire, 2002). Privatization, individualization (even for group class applications), and commercialization are the new facets of leisure. The body is undoubtedly the joining ring of everything that turns around this physical activity (PA) sub-sector and, today more than ever, fitness industry needs to take into consideration various untouchable features that bring users to the effective and actual service consumption (Figure 1). 


\section{Figure 1.}

Overall Body Facets (Smith Maguire, 2002; 2008)

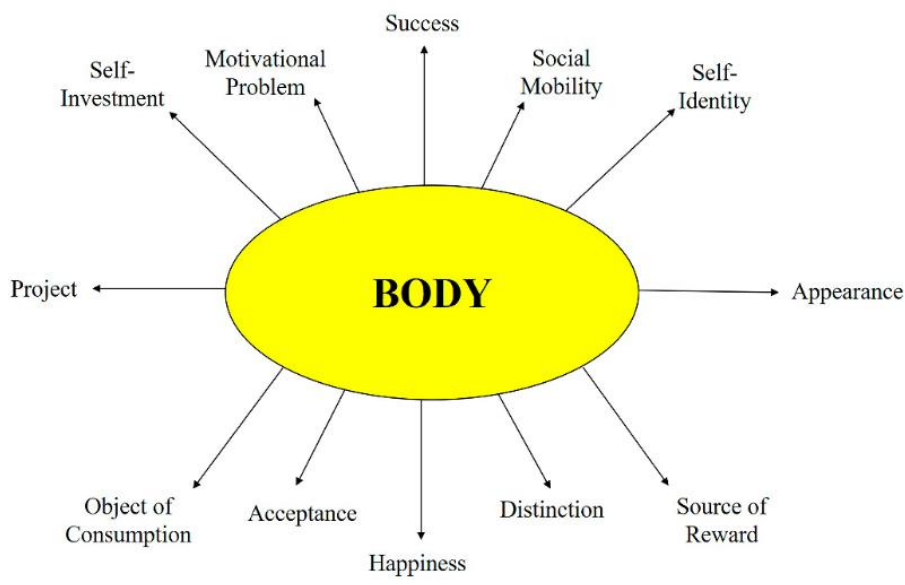

Source: Author.

It is necessary to stop thinking of fitness in terms of a workout or exercise-bout three times a week since fitness is a way to live. In today's modern world people might not be satisfied with their life if their body figure is not ideal with their expectations. Scientific narratives also focused on embodiment aspects: people who have become obsessed with their own image that are at risk of becoming engulfed by it, much like the Greek mythological figure of Narcissus (Edgley, 2006). Thus, exercise can be described as an important part of life because the results of the PA can affect an individual's life satisfaction and confidence. Each "devotee" selects his/her own rituals, through most rely on the principles of self-mortification and delayed gratification (Dawson, 2017).

For all these reasons, fitness should not be defined only as a commercial industry but, more appropriately, as a commercial-consumption cultural field (Smith Maguire, 2007; 2008). The growing boom of the leisure-health sector represents a predictor of the quality of life that a society aspires to belong to (Reverter Masia \& Barbany Cairo, 2007). Their activities are part of the spare time of every human being: initially, the industry milestones, sought affirmation along elitary contexts until embracing the defined Middle and New Middle Class(es); nowadays this global movement is not only tied to these social statuses (Annavarapu, 2018).

\section{Sectoral product-service definition}

Nowadays this community-based process leads to a wide variety of practices that underline customers traits such as engagement, perceived value, offer satisfaction, buyers future 
intentions, etc. The same are then reflected into the creation and correspondent commissioning of business models, demanded by global collectives and the named fresh fitness studio "boutique" tend to accomplish all these features (García-Fernández et al., 2020a).

Contemporary physical products or non-material services are not defined by what they are but by what they will be and what kind of potential they include (Addolorato, 2018a). Applicability, economical specialty, and suitability aiming usability are the main qualities that manufacturers need to take into consideration during the overall production phases that in scientific literature also named product life-cycle or human-machine processes (Addolorato $e t$ al., 2020). These ever-growing possibilities of resource usages, which are changing constantly, could firstly create havoc among sector professionals who operate everyday inside this industry and secondly between the mass, who contribute to the effective exploitation of the referenced field.

Establishing exploration and exploitation capabilities inherent in what is offered, and providing marketing and technological resources, allow to gain dynamic competencies which are able to influence the degree of product innovation and the correspondents market performances (Yalcinkaya et al., 2007). Along scientific literature is already studied that a general firm/brand conduct, aiming the creation of a novelty-centered business models, coupled with product market strategies that emphasize differentiation, cost leadership, or early market entry (Zott \& Amit, 2008). A product-service related business model corresponds to an emerging and new unit of analysis highlighting a system-level, or holistic approach, in order to explaining how firms normally "do business" (Zott et al., 2011). Manufacturers or producers activities cover an important role in the various conceptualizations stages of economic paradigm that they are able to propose, and these practical actions seek to explain how value is created and not just captured.

\section{Route to fitness studio boutique}

Franchising business models are among the latest schemes available inside postmodern societies, and the fitness industry is not aside from this global trend touching tangible spheres such as physical movements or sectoral professionalism (Andreasson \& Johnasson, 2018). This representation is widely and increasingly used by entrepreneurs seeking growth through geographical expansions, local managerial enterprises, outlet/retailing regularisation sizes, creating flexible and mobile customers, valuable franchisor inputs, and royalty rates definition 
(Gillis \& Castrogiovanni, 2012). Among observable strengths there are brand recognition, lower failure risk, easy setup, equipped customer potential portfolio, and easy to find financial support; instead, between opportunities there are the entrepreneurial tangible opportunity for the franchisee and real exploitation chances in the interested market share to persuade (Salar \& Salar, 2014). As said, during the past decades, a growing number of health franchising schemes have emerged in developing countries (Ruster et al., 2003); but to the respect of scientific evidences an initial lack of contributions or overall interest has been evidenced regarding the authentic fitness field. Thus, possessing these points of comparison (with general guidelines or from others adjacent sectors), has been found that limited efforts have been undertaken in sports leisure and management studies to examine market and business models among fitness settings available and the development routes undertaken until now (Knorr Cetina, 2000).

For this reason and against this preliminary backdrop, through a comprehensive systematic analysis, the purpose of this research is to understand the development of existing business and market setting configurations during the most recent era of fitness industry (Meyer et al., 2017). This study is able to identify relevant articles published in the last (almost) forty years, that correspond to the postmodern and busiest time frame in the entire industry timeline, and to what the sector has been able to put into practice impacting international societies. The current paper was guided by the broad investigative question: "is the available scientific literature offering the traits of these evolutions and trades confirmations-expansions? And this provided version, is in line with what has happened (and is still happening) in the real world practice of the same fitness business field?".

Accordingly, following a theoretical approach and in order to answer the aforementioned question, has been able to include the transition from the $1^{\text {st }}$ to $2^{\text {nd }}$ generation of franchises, with its mayor traits, of fitness industry through the effective definition of the qualitative aspects of the boutique "essence", until the social responses which currently define and present this sectoral final/ready to use offers along international contexts and environments. The adopted approach could create attractiveness for all current and future entrpreneurs/practitioners acting inside fitness sector and refine the expertise level domains inside sport and leisure management scientific literature. 
Addolorato, S., García-Unanue, J., Gallardo, L., \& García-Fernández, J. (2022, jan./abr.). Fitness industry business models: from the traditional franchising chain to the fitness boutique

\section{Methodology}

The chosen method was a systematic literature analysis which involved a comprehensive and variegated search for relevant knowledge and articles with a specific aim. Being a voluntarily targeted and bounded area of research, in this case, the right definition for this kind of analysis is the mini-review and corresponding thematic synthesis (Ong et al., 2016; Thomas \& Harden, 2008). Those identified and selected contributions were then appraised and summarized; during this process the objective was to evaluate the focused and useful contents for the preparation of a generalizable knowledge, according to the type of extraction that the same studies offered (De Lyon et al., 2017). The skill consists in being able to appraise which papers would be relevant for the aforethought scope in a broad scenario of sectors/research areas that could provide pertinent information. Hence, the final goal was to analyse an initial extensive, eclectic and large body of literature in order to understand the current state of the art, which in this case is in regard to the fitness industry related market and business models. The analysis started in September 2018, and the latest official search was performed on $31^{\text {st }}$ December 2018. Data collection was performed by one independent investigator experienced in product-service international management and exploitation of resources in the health \& fitness field.

\section{Data sources and searches}

Starting with three main databases (ISI-WoS, Scopus, and Sport Discus), the keywords used for the searches were as follows: fitness, chain, studio, and franchise. The first term has been intersected (dependent variable), using a Boolean logic "AND", with the remaining three independent ones. The references of each selected paper were assessed by using the known "snowball" technique to identify other potentially relevant papers that were not included among the indexed databases utilised (Atkinson \& Flint, 2001; Trost, 1986). With this additional inclusive logic, articles from other electronic investigation sources (not only academic papers but also customized case reports and sectoral magazine contributions) were used to enlarge the systematic literature analysis offered. The reference list also includes papers obtained from the following sources: Academic Search Complete, CINAHL, Cochrane Library, PsycINFO, Ergonomic Abstracts, Business Source Premier, Science Direct, and Google Scholar (De Lyon et al., 2017). The direct utilization of the specific word "boutique" (initially named as studio in scientific literature), as a keyword inside the selected database, has been discarded due to the 
current shortage of studies that use this fresh nomenclature, which is definitely more common in the everyday practice (e.g., at a didactic level, it is now only used in available private sectoral reports or conference proceedings).

\section{Study selection and methodological quality assessment}

The inclusion criteria of the selected articles were as follows: (1) articles were sorted with no limit on investigation areas; (2) publications related to the content criteria for "fitness" that were published through academic journals and directly intersected (Boolean logic 'AND') with the topics of "chain", "studio" and "franchise", that should only appear in the title; (3) when topics were not included in the title record, an extensive analysis was carried out to check if the matter subjects were faced or treated between the offered contents of abstracts, keywords, or the full-text article versions; and (4) papers written in English and Spanish, the two most used languages in the chosen databases (Table 1).

\section{Table 1.}

Literature Analysis Criteria and Approaches

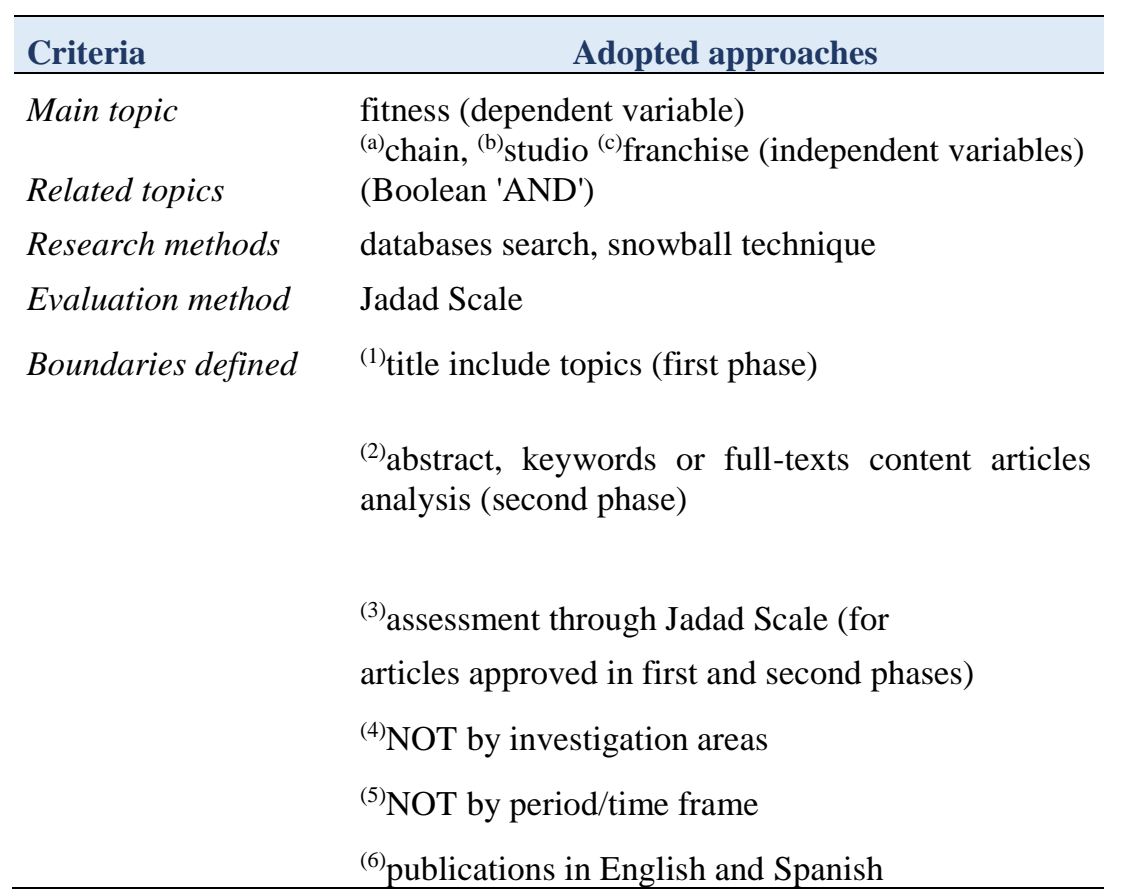

Source: Author.

Once the relevant publications for the definition of the state of the art were finalised, the Jadad Scale was used to systematically determine the quality of the papers for approval and 
acceptance (Clark et al., 1999; Jadad et al., 1996). The standard set for selection was for all articles that earned a punctuation of 3 (or more) points, which is an indication of high quality. As example, if one examined full-text paper separately faces only one of the pre-determined search keywords, did not obtain the minimum score to be listed in the focused literature analysis. The titles and abstracts sorted were screened to remove irrelevant or duplicated publications. The full-text versions of the remaining papers were then read, analysed, and assessed in detail to identify their final eligibility.

All of the papers were categorised according to their nature by the criteria of the reviewer who proceeded to sort them in three main themes, and performing a thematic synthesis (Franco et al., 2015; Morton et al., 2010; Thomas \& Harden, 2008): (1) Franchise: from $1^{\text {st }}$ to $2^{\text {nd }}$ generation (through intermediate seasonal shades); (2) The boutique "essence"; and (3) Social Responses.

\section{Databases}

The starting search exposed 121 contributions. However, most were eliminated based on repetitive appearances among the three indexed databases assessed (total of 33 articles selected) or an article's main topics discrepancy (title, keyword, abstract), and mostly full text contents that had nothing to do with the relevant subject matter for this study (Table 2). Ultimately, 26 articles met the criteria and a total of 8 additional sectoral case reports were deeply eviscerated. 
Addolorato, S., García-Unanue, J., Gallardo, L., \& García-Fernández, J. (2022, jan./abr.). Fitness industry business models: from the traditional franchising chain to the fitness boutique

Table 2.

Number of Articles According to the Descriptors

\begin{tabular}{|c|c|c|c|c|c|}
\hline Databases & \multicolumn{3}{|c|}{ Keywords } & Total & Selected \\
\hline \multirow[t]{3}{*}{ ISI (WoS) } & \multirow{3}{*}{ fitness } & \multirow{3}{*}{$A N D$} & chain & 9 & 2 \\
\hline & & & studio & 8 & 3 \\
\hline & & & franchise & 1 & 3 \\
\hline \multirow[t]{3}{*}{ Scopus } & \multirow{3}{*}{ fitness } & \multirow{3}{*}{$A N D$} & chain & 28 & 6 \\
\hline & & & studio & 16 & 2 \\
\hline & & & franchise & 1 & 0 \\
\hline \multirow[t]{3}{*}{ SportDiscus } & \multirow{3}{*}{ fitness } & \multirow{3}{*}{$A N D$} & chain & 9 & 3 \\
\hline & & & studio & 17 & 4 \\
\hline & & & franchise & 8 & 1 \\
\hline \multirow{3}{*}{$\begin{array}{l}\text { additional } \\
\text { databases }\end{array}$} & \multirow{3}{*}{ fitness } & \multirow{3}{*}{$A N D$} & chain & 7 & 4 \\
\hline & & & studio & 11 & 3 \\
\hline & & & franchise & 6 & 2 \\
\hline & & & & 121 & 33 \\
\hline
\end{tabular}

Source: Author.

This current subdivision (keywords and databases approached) allows us to understand the various available steps encountered in the fitness industry market and business models timeline, which will be explained in detail in the following results presentation paragraph.

\section{Results presentation}

Franchise: from $1^{\text {st }}$ to $2^{\text {nd }}$ generation (through intermediate seasonal shades)

The last (more than) 30-years of the industry's timeline have shown various changes in terms of how this cultural field could continuously offer fresh proposals to the worldwide active audience. Of course, these stages are not fully divided in every single step (a logical continuity was provided), but the final transition need to be taken under consideration by all sectoral practitioners (Figure 2). The globalization of service industries brings about new forms of organizing foreign business activities and mechanisms of international expansions which do not exist in the traditional manufacturing/commercial sub-field before their appearance (Parviainen, 2011). In the recent history of fitness, the most utilized ways detected have been franchising, trademarks, brands, and licenses. New facets of these modalities have been taken into serious account, such as association, awareness, equity, perception, positioning, and recognition/recall (Williams et al., 2014). Of course, the fitness industry followed, with the 
proper proportions, the same guidelines that other sectors more powerful or developed did before.

Figure 2.

Fitness Business and Market Model Settings Transition (From $1^{\text {st }}$ to $2^{\text {nd }}$ Franchise Generations)

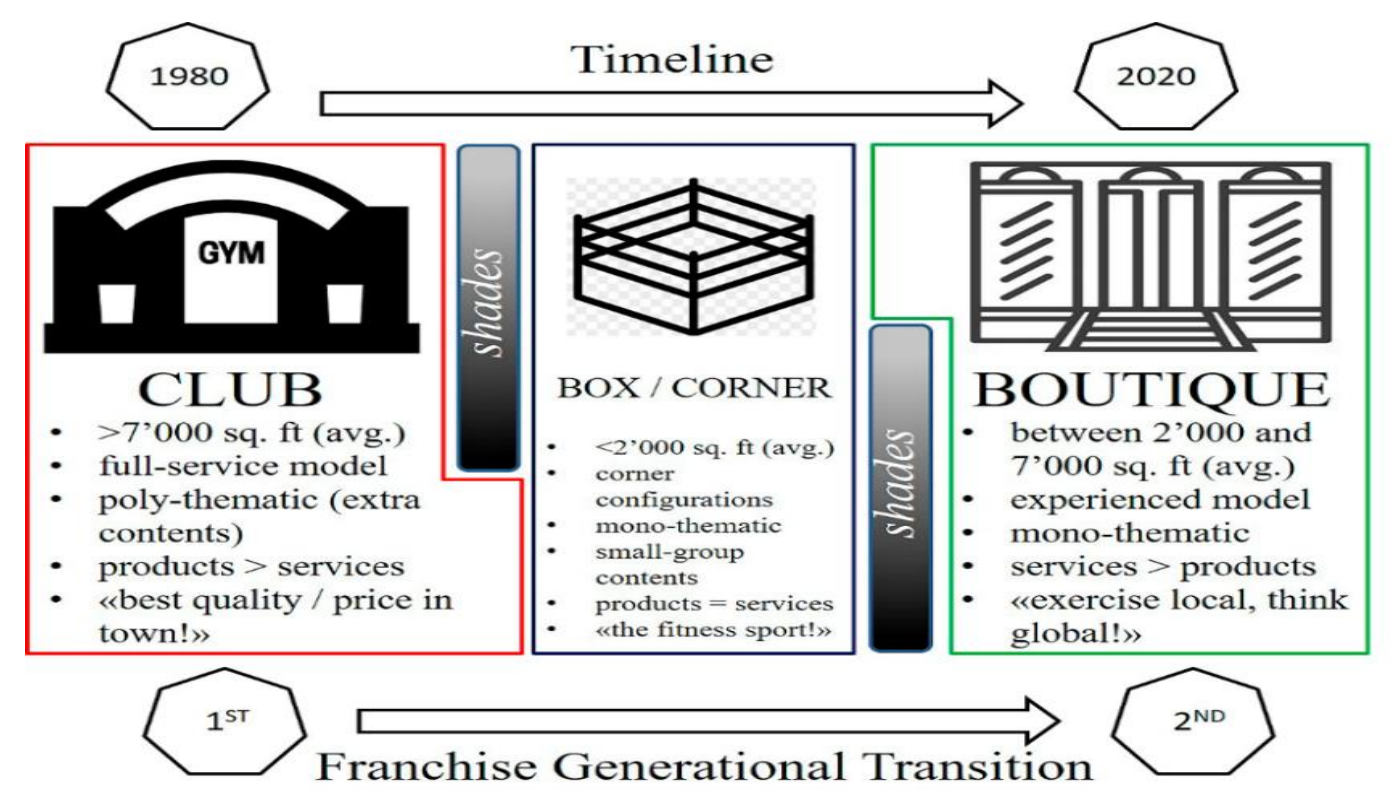

Source: Author.

In the 1990's the first "invasion" ( $1^{\text {st }}$ generation) of fitness franchises approached the Western societies under the name of big chain-firms who were relevant investors. The "fullservice" model of the Club started to offer something that users had never seen before: enormous facilities (averaged more than 7,000 sq. ft), continuous up-to-date weight and cardio training rooms, uncountable group class activities, swimming pools of every extraction, SPA and relaxation areas, racquetball or outdoor courts, and sometimes bars, restaurants, or kindergarten spaces (Fallon, 2004; Wells \& Ellsworth, 2016). All of these features were, averagely, offered with a 50\% discount, and opening timetables almost doubled compared with the existent competitors (Martínez Lemos \& González-Sastre, 2016). The following key success factors of this business model have been particularly studied even in the scientific literature: the strategic importance of the fitness business (only now seen, to all effects, like this), knowing the customer profiles available, providing a differentiated product (unexplored market segment), mastering technologies, employing diversified talents, practicing good 
Addolorato, S., García-Unanue, J., Gallardo, L., \& García-Fernández, J. (2022, jan./abr.). Fitness industry business models: from the traditional franchising chain to the fitness boutique

management, clear brand positioning, and being a smart marketer through traditional actions such as "exploding" offers, "unbelievable" claims/ad's, and various forms of day by day promotions (Chung Yuan et al., 2009; Parrot, 1996).

Subsequently the new millennium brings, from the US market, a new "shade" among the available fitness settings, The Box (Dawson, 2017). This phase also corresponds to the concept of the "McDondaldisation" of society, which includes predesigned and highly monitored programmes, apparent homogenisation in terms of global body ideals produced, a complex mixture of regulation - control - standardisation, and a struggle to express and transgress boundaries set by the (until that moment) commercial global fitness industry (Andreasson \& Johansson, 2016). Among the fundamental pillars of this innovative segment are the following: the underlined concept of do not exercise "together alone", voluntarism, performative regulation, mutual surveillance, and the mindset of the reinventive institutions of movement and PA. This stage creates a real maelstrom for the field by asking for even more specific attitudes among the beneficiaries of the services such as greed, identity, and community, until they approach new symbols comparable to a military-religious-exercise nexuses. These business models versions reinvent various schemes in terms of memberships (pay per use, utilised spaces) but especially the manners to perform the scheduled PA routines. These normally took place in unusual facilities, such as shed-like containers or a kind of warehouse, with mostly small configurations (less than 2,000 sq. ft). The ultimate aim of these new environments is the extreme forging of specific skills in the same sessions, such as agility, balance, cardiovascular/respiratory endurance, coordination, flexibility, performance accuracy, power, speed, stamina, and strength. Of course, not all of these PA qualities/traits are suitable for every kind of population that is active in front of trainers, but concepts creators tried to open the "borders" to most interested parties. Due to the reduced kinds of models, for example in terms of space investments, the $1^{\text {st }}$ generation of franchises felt "assaulted" by these active realities in the same market share, and most of them tried to (and did) incorporate this version of regulated movements inside the existing facilities that were already in their possession.

Here is how that took place, the named fitness schemes were called a Corner in which normal gymnasiums adapted their range of services including something (sometimes in a real corner of the facility spaces) that in the end was really close to what was offered by the box(es). It is for this main reason that both boxes \& corners couldn't be evaluated like a real step into a new version of fitness franchising model but, more accurately, could be defined as real seasonal "shades" which still exist and work. Anyhow, it must be admitted that in terms of content 
Addolorato, S., García-Unanue, J., Gallardo, L., \& García-Fernández, J. (2022, jan./abr.). Fitness industry business models: from the traditional franchising chain to the fitness boutique

features, these innovative applications contributed to the final definition of the subsequent real $2^{\text {nd }}$ generation of fitness franchising (Valcarce, 2016).

\section{The boutique "essence"}

The actual innovation provided in terms of fitness business settings available, which represents the last sectoral progress, is the Boutique (also labelled as $2^{\text {nd }}$ generation franchise). These realities, depending on the geographical location, are also called fitness "studios", not to be confused with personal training ones already existing for, at least, two decades in the same sectoral context subdivision.

Numerous indirect rules aimed at final consumers are enclosed in this kind of new concept, such as the motivation in learning and performing new skills, acting through impersonal co-motion, inter-passivity (unknowingly being part of a global "machinery"), and imitating entertainers (Parviainen, 2011). Certainly, some traits were definitely kept valid from the previous box/corner solutions that were already defined and metabolized along settings and societies globally. Several variables have been approached to analyse the current fitness boutique brands, both in the "real" life (metaphorically the leaves of the tree, the final and practical results) and in the scientific milestones (the roots, the foundation of an idea), which are conquering more and more market share at the international level.

Evidently, this development in terms of fitness business settings has brought a change and refinement in terms of market segmentation where cost leadership differentiation divide the trade into three main pricing levels: low-cost, medium and premium (Valcarce, 2016). The fitness boutique it is currently positioned in this last higher rank. Scientific literature gave a total of eight (8) main traits/qualitative variables/domains that a fitness boutique normally includes between its own characteristics and service supply.

- The first is undoubtedly the high (a) specialisation of the offer: each franchise selects one (or, at best, two) of the main training (workout) areas. For this segment, the most common sorts have been body-mind (new age) techniques, boxing (and/or mixed martial arts), indoor cycling, fusion (mixed skills in the same session), and cross training (IHRSA, 2016). Of course, the fundamental aptitudes on which they are based do not differ much from the classic basis of the science of movement (and from the focuses of the box settings, by e.g.), such as overall stability (in different bodily attitudes), mobility (efficient moves, embracing the joints flexibility by stretching postures and relaxation techniques), power and strength (approaching 
the latest workout's facets such as H.I.I.T. - high intensity interval training - and the labelled "functional" one), and finally reaction, speed, or agility (based on gross and fine coordination capacities).

- Consequently, by contrast, more boutiques in the same environment offer a wide (b) variety in terms of proposals to the final consumers, who can choose the closest PA extraction that they are looking for at a given time (Liu, 2014; MacIntosh \& Walker, 2012).

- These two first aspects come to the term of the observed (c) proactive competition in which every single player is not scared about the "next door" competitor of the same segment (news from the $1^{\text {st }}$ franchise generation). It is often represented as a percentage of users selected to be active in more than one facility at the same time. Lately this trend is also driven by local (neighbourhoods, cities, etc.) PA-related "communities" that bring their members through different forms of movement in a defined amount of time (Hurley, 2004; Lloyd, 2005; LunaAroca \& Li-Ping Tang, 2005; Maconachie \& Sappey, 2013; Surujlal \& Dhurup, 2012; Tawse \& Keogh, 1998).

- The next inspected key point is the (d) differentiation and unavoidable oriented sample segmentation. This is one biunivocal variable that unites the proposal contents and the related appropriate public. The current framework is both represented by organization (price, place, etc.) and market-induced (word-of-mouth, electronic word-of-mouth, and in general more organic communication methods) antecedents (Williams et al., 2014).

- Another fundamental point is the strong (e) methodological approach. These provided training methods bring fresh ways to activate, by engaging manners, the reduced group of people who interact with the session (mixed product-service solutions) delivered (Mawson, 1993; Polyakova \& Ramchandani, 2020).

- This last point leads to the extreme (f) care of details and effective customer orientation. The focal and tangible objects in which these details vary are from the facility design, through commercial training equipment, and the meticulously chosen types of lights to the new technologies included in the offer that bring a real and unique exercise "experience" or "servicescape" - service plus landscape - (Bitner, 1992). Among these basilar variables, music plays a fundamental role, especially in accompanying the different stages of PA. It is provided to engage, even more, the final audience (Felstead et al., 2007). The current product-service perspective is based on technology-mediated resources, most of them opened to the interoperability, so people could perceive a higher level of sense of place and a sort of positive addiction (Winchester \& Washington, 2015). The most widespread tools during this era of 
Addolorato, S., García-Unanue, J., Gallardo, L., \& García-Fernández, J. (2022, jan./abr.). Fitness industry business models: from the traditional franchising chain to the fitness boutique

connected fitness technologies are the massive use of fitness trackers (García-Fernández et al., $2020 b$ ), but inside these stages of new technologies adopted by the sector, there is also undoubtedly the proximity provided by the online app available in every portable device (IT for reservations, payments, promotions, and social-interaction among participants, and an online network of potential ones such as gamification, etc., for targeted purchasers awards or accumulate intangible points aiming engagement and fidelity). The users' perceptions, regarding the motivational climate, include task- and ego-involving, such as proper behaviour, commitment to exercise, and general life satisfaction (Brown \& Fry, 2014; Polyakova \& Ramchandani, 2020). The side of the ultimate consumer focus is in terms of the feelings of inclusion (higher than in the previous fitness settings that clients are probably coming from) and the actual sensation of hospitality. As already affirmed, this creates a positive atmosphere to generate these PA-oriented communities (new healthy habits). They are aimed at spreading group socialization, largely inside the New Middle Class segment. These exercise programs also foster a sense of social belonging in addition to greater self-reported health and energy (Wayment \& McDonald, 2017).

- Even the (g) location (physical place) plays a central role among the key variables of a regular fitness boutique. For example, this includes the context in which the centre is ubicated (street, neighbourhood, city, etc., depending on the selected environment), the average facility's dimensions (normally between 2,000 and 7,000 sq. ft), and the real estate actions required (rented spaces in most of the cases encountered). Between the main active players, additional related aspects assessed have been the available sample (local population generally needs to be over 200 thousands units, in order to be taken into consideration for opening a new flagship facility), the average purchasing power of the interested area (occupational or residential), and overall PA focal category preferences (Addolorato, 2018b).

- Finally, there is the overall concept of (h) optimization adopted. This "minimal" attitude includes humans (such as employees and/or sector professionals involvement) and interior/property factors (absence of stunning receptions, lounges, SPA, food \& beverage sections, and sometimes also expanding to the unusual lack of changing rooms) as ways to amortize overall costs for a local franchisee (Figure 4). 
Figure 4.

The Boutique Essence Graphical "Experience” View

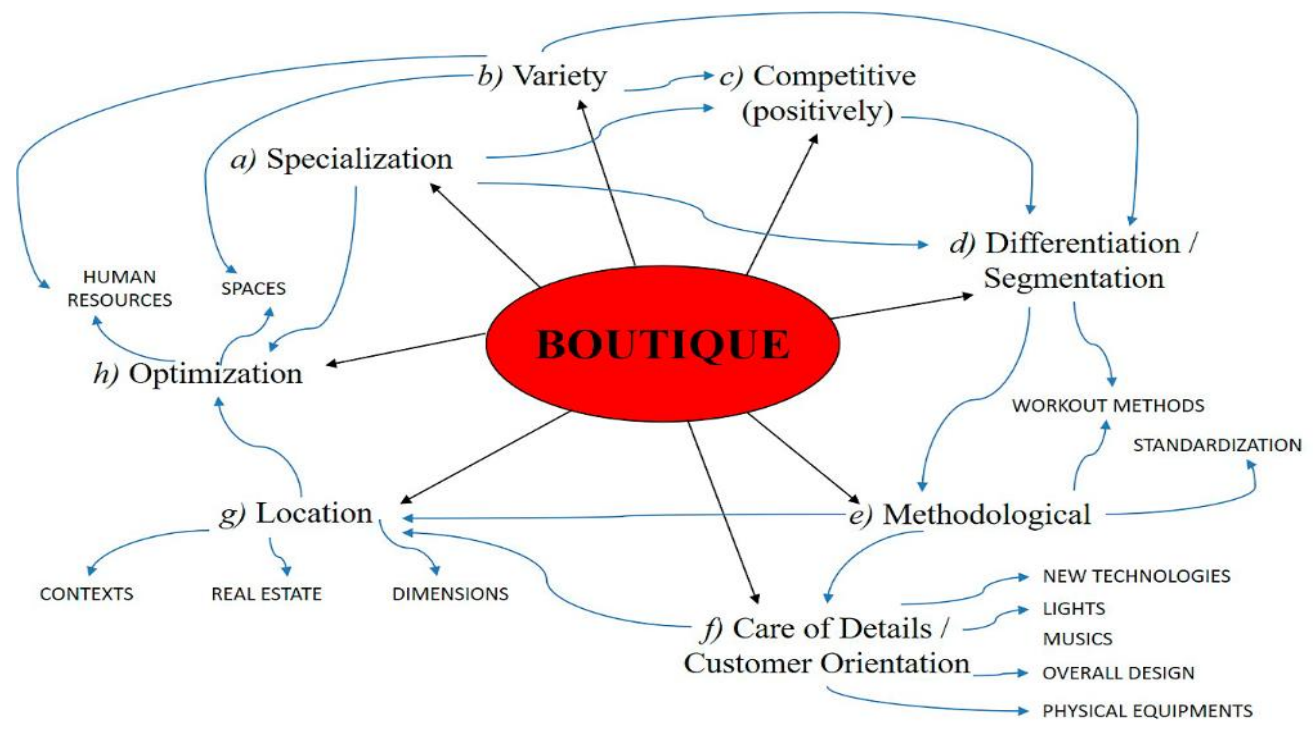

Source: Author.

\section{Social responses}

As detected, when approaching this suggested but complex topic of the fitness industry, such as the boutiques is, there are valid contributions in the scientific literature but they are still weak, embracing the generalizable view of the development listed for each setting focus. Even more, when articles try to embrace the social/psychological spheres of the environments whom take benefits from these kind of spread exercise or PA applications.

A recent, European based, "photography" of the situation is one in which the evaluated variables included are age groups, new kinds of membership fidelities, time taken to reach the facility, previous experiences in other fitness settings, and overall customer perception of this kind of business model from the final consumer point of view (Valcarce et al., 2017). Gender and time consumed to reach the workout site didn't seem to be relevant aspects among the samples which have been assessed. The age groups that were more active in subscribing memberships and exercise have been 21-30 (late Millennials and fresh Generation Z) and 3140 (Millennials and late Generation X) years old, even the 41-50 (current Generation X) year olds are also becoming increasingly thick in the market share. The main reason for this could be related to the technology-mediated resources which are at the base of the boutique's method of work (service/supply/delivering). A part of the teenager group (under 20 years old) and more than three quarters $(75.6 \%)$ of the observed boutique population (including also the over 60 
years old users) come from being active clients inside previous fitness setting models. For all the reason above listed and the business model qualities obtained from scientific literature was possible to define the averaged six main traits of the boutique consumer (Table 3).

Table 3.

\section{Common Traits of Boutiques Consumers}

\begin{tabular}{l}
\hline Boutiques Consumers \\
\hline 1- targeted and refined PA goals \\
2- ex active user, coming from previous/ancient fitness schemes \\
3- ready to use fidelity's settings \\
4- technology-mediated $360^{\circ}$ interaction \\
5- social/community extraction \\
6- easy applicability and overall support needs \\
\hline
\end{tabular}

Source: Author.

Finally, it seems relevant that every age group admits to be in frequent contact $(70.2 \%)$ with the sector professionals who work inside the facility (information, support, behavioural motivation, PA contents in their mixed but contemporaneous forms, etc.). Although all things considered from a customer perspective, there will be a more competitive environment which can lead to a probable reduction in the number of brands available, with clear winners and losers (Fallon, 2004; Minton, 2018).

\section{Discussion}

Until now, limited academic efforts have been undertaken to examine business models among fitness settings available and the development paths attempted. Oppositely along scientific literature, several quality variables have been approached in order to analyse the current fitness boutique brands which are conquering more and more of the market share at an international level. This is a confirmation of the service industry's globalization which brings about new forms of arrangements, such as organization of foreign business activities, mechanisms of international expansions, etc., which undoubtedly don't exist in the traditional manufacturing/commercial sub-field (and correspondent $1^{\text {st }}$ franchising generation business models) before their appearance (Parviainen, 2011; Williams et al., 2014). Thus, corresponding to the busiest moment of the sector in these directions (in the last 40-years of the industry's timeline), it is clear how fitness settings and their related business models and market schemes have made important changes. This demonstrates the value of knowing how the key-factors of 
each stage lead to the subsequent phases, and only visionaries could take advantage of it. Clubs, Boxes, Corners, and Boutiques have been "eviscerated" both from the everyday practice experience (what is happening to all effects) and through scientific milestone contributions (concept and idea foundations).

Inside fitness industry, speaking of business models concentrated on innovation and digital-technological foundations, to date is complex to sort specific traits based on dynamic performances and competencies only based on the state of the art that science offers (GarcíaFernández et al., 2020b). For this reason a good input, mostly due to the decennial sectoral experience of the main investigator, lead to embrace different versions of contributions that could widen the range of action and amplify details aiming the final research scope (Addolorato, 2018a; IHRSA, 2016; Minton, 2018; Valcarce et al., 2017; Wells \& Ellsworth, 2016). A good point of interest is the intersection with the topic of how these configurations could develop themselves by taking as an example what happened in different but more developed fields (such as food \& beverage, varied supply/block chain areas, etc.) in terms of early market entry, pure brand development/differentiation, franchisors/franchisees relations and middle-long term agreements, and finally trademarks and licensing rights definitions with their continuous updating (Yalcinkaya et al., 2007; Zott \& Amit, 2008; Zott et al., 2011).

Consequently, according to what encountered in scientific databases inherent quantitative/analytical findings, especially when facing the franchising business setting, are completely forgotten for the field of fitness during the postmodern part of its industry timeline. Especially for factors and variables such as: franchisor-inputs/franchisee-outputs, geographical expansions/adaptations forms or tools, sampling ROI (Return On Investment) plans or forecasting drafts/simulations (Gillis \& Castrogiovanni, 2012; Ruster et al., 2003). Either the previous (in comparison to business model exploration/definition/exploitation) product life cycle or human-machine process seemed to be left in the background, both for science and the targeted for-profit reports of the field (Addolorato, 2018b).

For all the aforementioned reasons, the only way to keep focused on the analysis of this fitness industry sub-field is through the concept that the real attempt needs to be the sociological definition of a cultural as well as a technology-mediated sector where the involvement of the human ego and special PA tasks, or new personal goals, are at the foundation of the game at all of the pyramid levels. 
Addolorato, S., García-Unanue, J., Gallardo, L., \& García-Fernández, J. (2022, jan./abr.). Fitness industry business models: from the traditional franchising chain to the fitness boutique

\section{Strength and limitations}

Authors acknowledge evidence for both strengths and limitations to the approach adopted for reviewing and analysing the existing literature. The greatest strength has been to include a large and (mostly) qualitative variety of information, without being impeded by strict or inappropriate inclusion/exclusion criteria. Moreover, the iterative approach allowed us to refine the analysis based on newly discovered material throughout all of the analysis duration. The main limit is linked to the nomenclature adopted for scientific databases searches. During the snowball technique "rounds", it has been necessary to assess articles which used synonyms in order to include more valid sources and maintain the same adopted rating scale. In addition, our data make evident how sectoral enterprise realities, as well as international associations, probably due to information policies of privacy based on data-funding protection, mostly act to limit their own investigations (both at B2B and B2C levels) aiming targeted surveys that include only questionnaires based on for-profit topics. These normally annual contributions, for motivations not made public, don't usually become scientific knowledge published at scientificimpacted level.

\section{Conclusions}

With regards to the historical moment in which societies are finding themselves, a fair point of clarification is necessary in order to understand and define the needs of these postmodern ways to "do business" inside the sector. Since the beginning of the new millennium, opening the "doors" of the elite population in terms of product-service accessibility, the industry need to face business models applicable to the whole lifespan stages available in all the developed environments and ready to receive them (Addolorato et al., 2021). This is why manufacturers, associations, investors and all the sector professionals included in this movement need to take into consideration several intangible traits in order to decide to propose resources that will be used by means of defined business processes, such as the franchising schemes.

As said, the fitness industry is revealing, even more, that it is a real commercial-cultural field. It is a wide network of producers, practitioners, practices, products, services, and "devotees" that never sleeps. Fitness settings and their main traits, such as Club, Box, Corner and Boutique help to define all of those aspects which are not possible to immediately realize at a first sight but are always present and relevant in the latest leisure and fitness business and 
market models, and everyday practice, by knowing the main steps seen during the last assessed decades. According to what was sorted both from scientific milestones (symbolically the roots of the tree) and the "real" life results (its leaves) and vice versa, the reader is able to understand the qualitative secrets of the franchising schemes and their progressions. This aids in understanding what to keep and what to "throw away" during every stage and to eventually foresee what could happen in the further industry developments.

In the specific case of this paper, the eight (8) main domains obtained for the fitness boutique model are the following (in alphabetical order): customer orientation (full care of details), differentiation/segmentation, location, methodology (rigorously defined and prepackaged systems), optimization (human resources, spaces, etc.), proactive competition avoiding the rivalry "frightening" and, finally, proposal specialization and, in the meanwhile, variety (between different players inside the same market share) of the offer. As detailed in the previous sections, this is a result of a mix of rewarding characteristics which came from "ancient" business configurations but, of course, also a step ahead with the addition of up-todate ones.

For all the motivated reasons is possible to affirm that science is offering only partial traits of the developments and trades confirmations-expansions in relation to the business of fitness. This is probably due to the "early maturation" stage of the industry in which one finds: in fact is reasonable to denote how in the daily practices, with its "real and tangible" actions, the sector is already offering much more advanced ideas (and, above all, in time with other fields initially with more historical phases behind, etc.) compared to what is accessible in publications of scientific impact. In further investigations, it seems necessary to pay attention on how settings (1) started to plan their own evolution paths from the initial traditional franchising chain and (2) in which manners are, nowadays, effectively applicable among the active user segments (social responses), with an approach to deepen (even more) all those untouchable but fundamental qualities that represent these latest fitness "experiences". Finally, for the near future, that another interesting research area could be the (3) local-to-global trade actions (Andreasson \& Johnasson, 2018), "concepts" movement and methods of diffusion that fitness enterprises are using to affirm themselves inside international markets. 


\section{References}

Addolorato, S. (2018a). Product or Service Tangible and Intangible Variables: the Creation of the Fitness Application 'Punnett Square' (FAPS). SPORT TK: Revista Euroamericana de Ciencias del Deporte, 7(2) (Supl. 2), 9-16.

Addolorato, S. (2018b). ¿Franchising? Tu centro fitness de confianza. bodyLIFE Spain, 1, 5659 http://findglocal.com/ES/Barcelona/144151625671922/body-LIFEEspa\%C3\%B1a.

Addolorato, S., García-Fernández, J., Gallardo, L., \& García-Unanue, J. (2020). An Overview of the Origins and Effectiveness of Commercial Fitness Equipment and Sectoral Corporate Settings: A Critical Review of Literature. Applied Sciences, 10(4), 1534.

Addolorato, S., García-Unanue, J., Gallardo, L., \& García-Fernández, J. (2021). Do Scientific Approaches Lead to Innovative Social Entrepreneurial Ventures? The Relationship between Fitness Equipment and Stages of Life. In Innovation and Entrepreneurship in Sport Management. Edward Elgar Publishing.

Andreasson, J., \& Johansson, T. (2016). 'Doing for Group Exercise what McDonald's did for Hamburgers': Les Mills, and the Fitness Professional as Global Traveller. Sport, Education and Society, 21(2), 148-165.

Andreasson, J., \& Johansson, T. (2018). Glocalised Fitness: The Franchising of a Physical Movement, Fitness Professionalism and Gender. Leisure/Loisir, 42(3), 301-321.

Annavarapu, S. (2018). Consuming Wellness, Producing Difference: The Case of a Wellness Center in India. Journal of Consumer Culture, 18(3), 414-432.

Atkinson, R., \& Flint, J. (2001). Accessing Hidden and Hard-to-reach Populations: Snowball Research Strategies. Social Research Update, 33(1), 1-4.

Bitner, M. J. (1992). Servicescapes: The impact of Physical Surroundings on Customers and Employees. The Journal of Marketing, 56(2), 57-71.

Brown, T. C., \& Fry, M. D. (2014). Motivational Climate, Staff and Members' Behaviors, and Members' Psychological Well-being at a National Fitness Franchise. Research Quarterly for Exercise and Sport, 85(2), 208-217.

Chung Yuan, B. J., Liu, C. Y., Kao, K. M., \& Hsu, Y. C. (2009). Entrepreneurship and Innovation Process in the Health Industry in Taiwan, European Business Review, 21(5), 453-471.

Clark, H. D., Wells, G. A., Huët, C., McAlister, F. A., Salmi, L. R., Fergusson, D., \& Laupacis, A. (1999). Assessing the Quality of Randomized Trials: Reliability of the Jadad Scale. Controlled Clinical Trials, 20(5), 448-452.

Dawson, M. C. (2017). CrossFit: Fitness Cult or Reinventive Institution?. International Review for the Sociology of Sport, 52(3), 361-379. 
De Lyon, A. T., Neville, R. D., \& Armour, K. M. (2017). The Role of Fitness Professionals in Public Health: A Review of the Literature. Quest, 69(3), 313-330.

Edgley, C. (2006). The Fit and Healthy Body: Consumer Narratives and the Management of Postmodern Corporeity. Body/embodiment: Symbolic Interaction and the Sociology of the Body, 231-245.

Fallon, J. (2004). New Thinking on Health and Fitness. Journal of Retail \& Leisure Property, 3(4), 307-313.

Felstead, A., Fuller, A., Jewson, N., Kakavelakis, K., \& Unwin, L. (2007). Grooving to the Same Tunes? Learning, Training and Productive Systems in the Aerobics Studio. Work, Employment and Society, 21(2), 189-208.

Franco, M. R., Tong, A., Howard, K., Sherrington, C., Ferreira, P. H., Pinto, R. Z., \& Ferreira, M. L. (2015). Older people's Perspectives on Participation in Physical Activity: A Systematic Review and Thematic Synthesis of Qualitative Literature. British Journal of Sports Medicine, 49(19), 1268-1276.

García-Fernández, J., Gálvez-Ruiz, P., Sánchez-Oliver, A. J., Fernández-Gavira, J., Pitts, B. G., \& Grimaldi-Puyana, M. (2020a). An Analysis of New Social Fitness Activities: Loyalty in Female and Male CrossFit users. Sport in Society, 23(2), 204-221.

García-Fernández, J., Gálvez-Ruiz, P., Grimaldi-Puyana, M., Angosto, S., Fernández-Gavira, J., \& Bohórquez, M. R. (2020b). The Promotion of Physical Activity from Digital Services: Influence of E-lifestyles on Intention to Use Fitness Apps. International Journal of Environmental Research and Public Health, 17(18), 6839.

Gillis, W., \& Castrogiovanni, G. J. (2012). The Franchising Business Model: An Entrepreneurial Growth Alternative. International Entrepreneurship and Management Journal, 8(1), 75-98.

Glassner, B. (1989). Fitness and the Postmodern Self. Journal of Health and Social Behavior, 180-191.

Hurley, T. (2004). Managing Customer Retention in the Health and Fitness Industry: A Case of Neglect. Irish Marketing Review, 17(1/2), 23-29.

International Health, Racquet \& Sportsclub Association (2016). IHRSA's Guide to the Boutique Studio Phenomenon. Boston, MA: IHRSA.

Jadad, A. R., Moore, R. A., Carroll, D., Jenkinson, C., Reynolds, D. J. M., Gavaghan, D. J., \& McQuay, H. J. (1996). Assessing the Quality of Reports of Randomized Clinical Trials: Is blinding necessary?. Controlled Clinical Trials, 17(1), 1-12.

Knorr Cetina, K. (2000). Postsocial Theory. In: Ritzer G. and Smart B. (Ed.). Handbook of Social Theory. London: Sage, 520-537. 
Addolorato, S., García-Unanue, J., Gallardo, L., \& García-Fernández, J. (2022, jan./abr.). Fitness industry business models: from the traditional franchising chain to the fitness boutique

Liu, L. (2014). Research on the Development Strategies of the Urban Fitness Coaches in Qingdao. Asian Social Science, 10(11), 225-232.

Lloyd, C. (2005). Competitive Strategy and Skills: Working Out the Fit in the Fitness Industry. Human Resource Management Journal, 15(2), 15-34.

Luna-Aroca, R., \& Li-Ping Tang, T. (2005). The Use of Cluster Analysis to Segment Clients of a Sport Center in Spain. European Sport Management Quarterly, 5(4), 381-413.

MacIntosh, E. W., \& Walker, M. (2012). Chronicling the Transient Nature of Fitness Employees: An Organizational Culture Perspective. Journal of Sport Management, 26(2), 113-126.

Maconachie, G., \& Sappey, J. (2013). Flexing Some Muscle: Strategy and Outcomes in the Queensland Health and Fitness Industry. Journal of Industrial Relations, 55(1), 136154.

Martínez Lemos, I., \& González-Sastre, B. (2016). The Spanish Fitness Market: An Exploratory Study of the Economic Profile of this Low-cost Segment. CCD. Cultura_Ciencia_Deporte. 文化-科技-体育, 11(33), 197-206.

Mawson, L. M. (1993). Total Quality Management: Perspectives for Sports Managers. Journal of Sport Management, 7(2), 101-106.

Meyer, J., Morrison, J., \& Zuniga, J. (2017). The Benefits and Risks of CrossFit: A Systematic Review. Workplace Health \& Safety, 65(12), 612-618.

Minton, D. (2018). London Boutique Studio Report. LeisureDB (formerly The Leisure Database Company Ltd).

Morton, R. L., Tong, A., Howard, K., Snelling, P., \& Webster, A. C. (2010). The Views of Patients and Carers in Treatment Decision Making for Chronic Kidney Disease: Systematic Review and Thematic Synthesis of Qualitative Studies. The British Medical Journal, 340, c112.

Ong, A. D., Uchino, B. N., \& Wethington, E. (2016). Loneliness and Health in Older Adults: A Mini-review and Synthesis. Gerontology, 62(4), 443-449.

Parrot, D. L. (1996). Whose Business is Fitness?. Journal of Health Care Marketing, 16(3), 44-49.

Parviainen, J. (2011). The Standardization Process of Movement in the Fitness Industry: The Experience Design of Les Mills Choreographies. European Journal of Cultural Studies, 14(5), 526-541.

Polyakova, O., \& Ramchandani, G. (2020). Perceived Service Quality among Regular Users of Gyms in Public Sports Centres in the UK. Managing Sport and Leisure, 1-20. 
Reverter Masia, J., \& Barbany Cairo, J. (2007). From the Gym to the Leisure - Health. Centers of Fitness, Fitness Center, Fitness \& Wellness, Spa, Thalassotherapy Center. Apunts. Educación Física y Deportes, 4(90), 59-68.

Ruster, J., Yamamoto, C., \& Rogo, K. (2003). Franchising in Health: Emerging Models, Experiences, and Challenges in Primary Care.

Salar, M., \& Salar, O. (2014). Determining Pros and Cons of Franchising by Using Swot Analysis. Procedia-Social and Behavioral Sciences, 122, 515-519.

Smith Maguire, J. (2002). Body Lessons: Fitness Publishing and the Cultural Production of the Fitness Consumer. International Review for the Sociology of Sport, 37(3-4), 449464.

Smith Maguire, J. (2007). Fit for Consumption: Sociology and the Business of Fitness. Routledge.

Smith Maguire, J. (2008). Leisure and the Obligation of Self-work: An Examination of the Fitness Field. Leisure Studies, 27(1), 59-75.

Sternberg, E. (1996). A Case of Iconographic Competition: The Building Industry and the Postmodern Landscape. Journal of Urban Design, 1(2), 145-163.

Surujlal, J., \& Dhurup, M. (2012). Establishing and Maintaining Customer Relationships in Commercial Health and Fitness Centers in South Africa. International Journal of Trade, Economics and Finance, 3(1), 14-18.

Thomas, J., \& Harden, A. (2008). Methods for the Thematic Synthesis of Qualitative Research in Systematic Reviews. BMC Medical Research Methodology, 8(1), 45.

Tawse, E. L., \& Keogh, W. (1998). Quality in the Leisure Industry: An Investigation. Total Quality Management, 9(4-5), 219-222.

Trost, J. E. (1986). Statistically Nonrepresentative Stratified Sampling: A Sampling Technique for Qualitative Studies. Qualitative Sociology, 9(1), 54-57.

Valcarce, M. (2016). Sports Business Models: Evolution and Future. In J. García-Fernández (Ed.), Entrepreneurship in the Sport Sector: From the Theory to the Practice (pp. 113126). Cizur Menor: Aranzadi Thomson Reuters.

Valcarce, M., Cordeiro, C., \& García-Fernández, J. (2017). Boutique Report - Spain. Valgo ${ }^{\circledR}$ Fitness \& Sport Management (ISBN: 978-84-697-2492-7).

Wayment, H. A., \& McDonald, R. L. (2017). Sharing a Personal Trainer: Personal and Social Benefits of Individualized, Small-group Training. The Journal of Strength \& Conditioning Research, 31(11), 3137-3145.

Wells, J. R., \& Ellsworth, G. (2016). The Quiet Ascension of LA Fitness. (pp. 1-19, Tech. No. 9-717-424). Boston, MA: Harvard Business School Publishing. 
Williams, A. S., Rhenwrick, I., Wright, B., Choi, W., Kim, D., \& Vickey, T. (2014). Building Viable Fitness Brands: Importance of Brand Communication Strategies in Attracting Potential Health Club Members. International Journal of Sport Management, Recreation, \& Tourism, 15, 49-68.

Winchester, W. W., \& Washington, V. (2015). Realizing the Potential of Connected Fitness Technologies: A Case for Systems Engineering Involvement. INSIGHT, 18(4), 38-40.

Yalcinkaya, G., Calantone, R. J., \& Griffith, D. A. (2007). An Examination of Exploration and Exploitation Capabilities: Implications for Product Innovation and Market Performance. Journal of International Marketing, 15(4), 63-93.

Zott, C., \& Amit, R. (2008). The Fit Between Product Market Strategy and Business Model: Implications for Firm Performance. Strategic Management Journal, 29(1), 1-26.

Zott, C., Amit, R., \& Massa, L. (2011). The Business Model: Recent Developments and Future Research. Journal of Management, 37(4), 1019-1042. 